\title{
STRATEGI GURU PENDIDIKAN AGAMA ISLAM DALAM MENANGGULANGI TINDAKAN BULLYING SISWA
}

\author{
Syaiful Fuad1, Sumarwati2, Asma Naily Fauziyah³, Zaini Tamin AR4 \\ 'SMPN 2 Waru Sidoarjo, ${ }^{2}$ STAI YPBWI Surabaya, ${ }^{3}$ Universitas Sunan Giri Surabaya ${ }^{4}$ STAI YPBWI Surabaya
}

\begin{abstract}
ABSTRAK
Penelitian ini bermula dari pengamatan penulis sebagai guru di SMPN 2 Waru Sidoarjo, yang sering menemukan tindakan bullying yang dilakukan siswa. Dari kegiatan tersebut, penulis bersama tim melakukan penelitian yang bertujuan untuk mengetahui apa saja bentuk-bentuk tindakan bullying dan strategi guru Pendidikan Agama Islam (PAI) dalam menangani perilaku bullying pada siswa. Jenis penelitian yang digunakan adalah penilitian kualitatif deskriptif dengan pendekatan studi kasus. Penelitian ini menemukan bahwa, bentuk-bentuk aksi bullying yang dilakukan anak seperti mendorong badan teman, mengejek, menghina keluarganya, menendang, memukul, mendorong kepala, dan sebagainya. Strategi yang dilakukan guru PAI dalam menangani perilaku bullying ada tiga: pertama, strategi ceramah, memberikan arahan dan nasehat kepada siswa. Kedua, strategi hukuman yang diberikan dengan menghafal ayat-ayat pendek, membersihkan kelas, serta hukuman lain yang dirundingkan dengan pihak sekolah dan orang tua siswa. Penulis merekomendasikan beberapa hal: pertama, bimbingan kepada siswa harus dilakukan secara terus menerus, baik di sekolah, di rumah atau lingkungan masyarakat. Kedua, berkomunikasi secara intens dengan wali siswa. Kegiatan ini dilakukan untuk memberitahukan aktivitas siswa kepada orang tua dengan baik. Ketiga, guru harus mengutamakan keteladanan. Karena pembelajaran di kelas akan bermakna jika ditopang dengan teladan yang baik. Keempat, sekolah harus membuat aturan baku yang menjadi undang-undang untuk menggulangi Tindakan bullying siswa.
\end{abstract}

Kata Kunci: Bullying, Guru Pendidikan Agama Islam, Ceramah, Hukuman, Keteladanan.

\section{ABSTRACT}

This research stems from the author's observations as a teacher at SMPN 2 Waru Sidoarjo, who often finds bullying by students. From these activities, the authors conducted a study that aims to find out what forms of bullying acts and strategies for Islamic Religious Education Teacher teachers in dealing with bullying behavior in students. The type of research used is descriptive qualitative research with a case study approach. This study found that the forms of bullying carried out by children such as pushing their friends' bodies, mocking, insulting their families, kicking, hitting, pushing their heads, and so on. There are three strategies used by Islamic Religious Education teachers in dealing with bullying behavior: first, the lecture strategy, providing direction and advice to students. Second, the punishment strategy is given by memorizing short verses, cleaning the classroom, and other punishments that are negotiated with the school and parents. The author recommends several things: first, guidance to students must be carried out continuously, whether at school, at home or in the community. Second, communicate intensely with the guardians of students. This activity is carried out to inform parents of student activities properly. Third, teachers must prioritize exemplary. Because learning in class will be meaningful if it is supported by good examples. Fourth, schools must make standard rules that become laws to combat student bullying

Keywords: Bullying, Islamic Religious Education Teacher, Lecture, Punishment, Exemplary. 


\section{A. Pendahuluan}

Bullying telah diakui sebagai masalah yang relevan dan serius oleh beberapa badan internasional. Pada tahun 1996, Majelis Kesehatan Dunia mengadopsi resolusi yang menyatakan kekerasan sebagai masalah kesehatan masyarakat utama di seluruh dunia dan meminta Negara-negara Anggota untuk segera mempertimbangkan masalah kekerasan. Dalam konteks sekolah, peer Bullying adalah bentuk kekerasan paling umum di kalangan anak-anak dan remaja. Bullying membahayakan hak-hak anak, termasuk hak atas pendidikan seperti yang diminta oleh Konvensi Hak Anak (Perserikatan BangsaBangsa 1989). Ini menghadirkan risiko khusus bagi anak-anak yang rentan, seperti anakanak penyandang disabilitas; pengungsi, atau anak-anak yang terkena dampak migrasi; anak-anak yang dikucilkan; anak-anak yang termasuk dalam kelompok minoritas, atau hanya anak-anak yang berbeda dari kelompok sebaya. ${ }^{1}$.

Perilaku Bullying adalah niat jahat, ketidakseimbangan kekuatan, pengulangan, kesusahan, dan provokasi. Bullying di sekolah dapat terjadi baik di sekolah, di kampus, atau di luar sekolah, tetapi ini disebabkan oleh hubungan yang dibuat di lingkungan sekolah. Perilaku Bullying melibatkan niat untuk menyakiti dan ketidakseimbangan kekuatan antara penyerang dan korban, dan itu terjadi berulang kali. ${ }^{2}$ Bullying melibatkan interaksi dinamis antara pelaku dan korban. Kekuatan penindas meningkat, dan korban kehilangan kekuasaan. Akibatnya korban sulit merespon atau mengatasi masalah tersebut Ketidakseimbangan kekuasaan dapat berasal dari kekuatan fisik, status sosial dalam kelompok, atau dari ukuran kelompok (misalnya kelompok yang menargetkan satu orang). Kekuasaan juga dapat diperoleh dengan mengetahui kerentanan seseorang (misalnya penampilan, masalah belajar, situasi keluarga, karakteristik pribadi) dan menggunakan pengetahuan ini untuk menyakitinya. ${ }^{3}$

Permasalahan internal maupun eksternal seolah-olah membentuk rantai yang sulit diputuskan, meskipun begitu harus segera diupayakan solusi pemecahannya. Kemorosotan moral di kalangan peserta didik menyebabkan melemahnya karakter (akhlak) siswa. ${ }^{4}$ Gejala ini diakibatkan oleh lemahnya sistem pendidikan dalam membentuk perilaku atau karakter siswa bahkan pembelajaran agama Islam saja

${ }^{1}$ K. A. Fanti, \& E. Kimonis, "Bullying and victimization: The role of conduct problems and psychopathic traits", Journal of Research on Adolescence, Vol. 22 (2012): 617-631.

2 D. F. Farrington, “Understanding and preventing bullying”, Crime and Justice, Vol. 17 (1993): 381-458.

3 S. Hymel \& S.M. Swearer, "Four decades of research on school bullying: An introduction", American Psychologist, Vol. 70 (2015): 293-299.

${ }^{4}$ Lihat, Thomas Lickona, Educating for Character: How Our Schools Can Teach Respect and Responsibility (New York : Bantam Books., 1991). 
dikesampingkan sebagai pelengkap dalam pembelajaran. Padahal pembelajaran agama harus ditegaskan dan menjadi prioritas utama dalam membentuk karakter siswa agar menjadi siswa yang berakhlakul karimah. ${ }^{5}$

Tetapi saat ini khusus di kalangan siswa-siswi, berbagai kasus melemahnya moral dan akhlak peserta didik sering kali terjadi dan bahkan mengkhawatirkan. Berbagai perilaku menyimpang (Bullying) sering mereka lakukan dengan berbagai tindakan seperti mengganggu temannya serta membuat keributan di lingkungan sekolah tersebut dan mengolok-oloknya. ${ }^{6}$ Padahal dalam Islam sangat dianjurkan bagi manusia untuk berbuat baik kepada sesama dan melarang perbuatan yang mencela atau merendahkan orang lain. Sebab sebagai makhluk-Nya sudah seharusnya saling membantu dalam kebaikan, bukan saling menjatuhkan dan merendahkan. Sebagaimana termaktub dalam al-Qur'an di surat Al-Hujurat ayat $11 .^{7}$

Perilaku Bullying ini terjadi karena pengawasan guru yang belum maksimal dan kurangnya moral baik dalam diri siswa itu sendiri, seorang guru harus mempunyai strategi dalam menagulangi siswa yang melakukan hal tersebut agar peserta didik merubah perilakunya dari yang tidak baik menjadi baik. Adapun yang menjadi ciri khas perilaku Bullying di SMP Negeri 2 Waru Sidoarjo adanya sebagian siswa membuat kelompok atau geng tersendiri berdasarkan temen di kampung mereka masing-masing yang kemudian timbul perilaku perilaku menyimpang (Bullying) baik kepada siswa lain maupun kepada kelompok lain.

Siswa sering membentuk kelompok tersendiri (Geng) dikarenakan banyaknya siswa yang masuk karena adanya sistem zonasi, di mana mereka sudah terbiasa berkumpul dengan kelompok di lingkungan rumah atau kampung mereka sehingga mereka merasa kuat dan merasa punya teman teman yang mendukungnya dan membuat -perilaku Bullying kepada siswa lain atau ke kelompok lain dan tak jarang terjadi tawuran antar teman karena ulah Bullying ini.

Berdasarkan hasil observasi awal yang dilakukan oleh penulis bahwa beberapa siswa di SMP Negeri 2 Waru Sidoarjo melakukan perilaku yang menyimpang yaitu aksi Bullying. Adapun aksi Bullying yang sering dilakukan oleh siswa di sekolah tersebut salah satunya adalah mengganggu temannya, contohnya mengejek, menghina keluarganya

\footnotetext{
${ }^{5}$ Hujair AH. Sanaky, "The Role of Religious Education in Forming Tolerant Individuals", Indonesian Journal of Interdisciplinary Islamic Studies, Vol. 1, No. 1 (September 2017).

${ }^{6}$ Katyana Wardhana, Buku Panduan Melawan Bullying (ebook: tp, 2016$), 9$.

7 Ahmad Hatta, Tafsir Qur'an Per Kata Dilengkapi Dengan Asbabun Nuzul \& Terjemah (Jakarta: Maghfirah Pustaka, 2009),516.
} 
sampai memanggilnya dengan julukan orang tuanya, "eh paimen" dll. Dengan sebutan seperti itu yang awalnya main-main dan bearkhir di perkelahian. Selain itu, memakimaki, memanggil nama dengan sebutan yang tidak baik, serta mempermalukan temannya, bahkan melakukan kekerasan fisik seperti memukul dan berbuat jail hingga melukai temannya. ${ }^{8}$ Semua ini dikarenakan kurangnya perhatian guru terhadap siswa khususnya guru pendidikan Agama Islam. Jika tidak diatasi maka akan berdampak pada siswa itu sendiri yang melakukan Bullying dan siswa yang menjadi korban Bullying yang mengakibatkan psikologis anak terganggu, akhlak siswa menjadi buruk dan tanpa arah tujuan. Jika terus berlanjut tanpa ada yang mengatasi maka siswa penerus bangsa Indonesia akan mengalami kemrosotan mental dan akhlaqnya. Seorang guru harus memiliki strategi atau cara untuk mengatasi prilaku Bullying tersebut agar peserta didik yang melakukan Bullying dan menjadi korban Bullying bisa merubah sifatnya atau perbuatannya menjadi siswa-siswi yang berakhlakul karimah.

\section{B. Bullying; Kasus dan Problem Pendidikan}

Bullying adalah bentuk kekerasan remaja yang lazim, terutama di lingkungan sekolah. Seperti yang diilustrasikan dalam contoh di atas, ini didefinisikan oleh perilaku agresif (yaitu, perilaku yang disengaja dan kejam) yang terjadi berulang kali dari waktu ke waktu dan dalam konteks ketidakseimbangan kekuatan. ${ }^{9}$ Meskipun keduanya berbahaya bagi remaja, ada perbedaan penting antara Bullying dan agresi - jika sesekali ada konflik atau pertengkaran antara dua anak yang memiliki kekuatan, ukuran, dan status sosial yang sama, ini adalah agresi, bukan Bullying. ${ }^{10}$ Bullying adalah perilaku agresif berulang yang ditandai dengan ketidakseimbangan kekuatan dan niat untuk menyakiti. Siswa yang di-bully sering kali merasa terancam dan tidak berdaya. Meskipun Bullying bisa merusak dan terus-menerus, hal itu juga bisa jadi cukup halus sehingga guru tidak menyadarinya. Karena Bullying dapat menyebabkan masalah psikologis, emosional, dan fisik yang berkepanjangan, penting bagi guru untuk mengenali tandatanda Bullying dan cara melawannya.. ${ }^{11}$

8 Observasi, di SMPN 2Waru Sidoarjo, 15 Februari 2020

${ }^{9}$ Aprilia Eunike Tawalujan, Dkk, "Hubungan Bullying dengan Kepercayaan Diri Pada remaja di SMP Negeri 10 Manado", e-Journal keperawatan, Vol. 6, No. 1 (Mei 2018): 2

10 Muhammad Fajar Shidiqi dan Veronika Suprapti, "Pemaknaan Bullying pada Remaja Penindas(The Bully), Jurnal Psikologi Keperibadian dan Sosial, Vol. 2, No. 2 (Agustus 2013): 23

11 Dian Fitri Nur Aini, "Self Esteem Pada Anak Usia Sekolah Dasar Untuk Pencegahan Kasung Bullying”, Jurnal Pemikian dan Pengembangan SD, Vol. 6, No. 1 (April 2018): 38. 
Bullying terdiri dari serangan verbal (misalnya memanggil nama, ancaman), perilaku fisik (misalnya memukul, menendang, merusak properti korban), dan agresi relasional / sosial (misalnya pengucilan sosial, penyebaran rumor) hingga bentuk serangan terbaru melalui Internet dan teknologi baru (juga disebut sebagai cyberBullying). ${ }^{12}$

Di ruang kelas, siswa serta seluruh sekolah, memiliki tingkat Bullying yang bervariasi. Karena variasi antara ruang kelas yang berbeda jauh lebih besar daripada variasi antar sekolah, kami fokus pada yang pertama. Faktor risiko tingkat kelas dapat dicari dari faktor demografis (seperti ukuran kelas), dinamika kelompok sebaya, atau karakteristik guru. Faktor demografis tampaknya tidak menjelaskan perbedaan tingkat kelas dalam Bullying dengan baik. Misalnya, tidak ada bukti yang jelas tentang ukuran kelas yang terkait dengan prevalensi pelaku intimidasi atau korban di kelas tersebut. Ketika sebuah asosiasi ditemukan, seringkali hal itu bertentangan dengan harapan umum: lebih banyak intimidasi ditemukan di ruang kelas yang lebih kecil daripada di ruang kelas yang lebih besar. Beberapa kandidat demografis lain juga gagal menjelaskan perbedaan antara ruang kelas (misalnya proporsi anak laki-laki di ruang kelas, proporsi imigran di ruang kelas), atau temuannya kontroversial. Perbedaan kelas dapat dijelaskan dengan lebih baik oleh faktor-faktor yang terkait dengan dinamika kelompok sebaya atau karakteristik guru. ${ }^{13}$

Hierarki kelas dikaitkan dengan perilaku Bullying: ada lebih banyak Bullying di ruang kelas yang sangat hierarkis, di mana status teman sebaya (seperti popularitas) atau kekuasaan (yang biasanya memutuskan tentang sesuatu) berpusat pada beberapa individu daripada didistribusikan secara merata. Dalam penelitian Garandeau, ditemukan bahwa hierarki kelas mengarah pada peningkatan Bullying dari waktu ke waktu, daripada Bullying yang mengarah ke peningkatan hierarki. Ruang kelas nonhierarkis, di sisi lain, bukanlah lingkungan yang mendukung untuk berkembangnya intimidasi. $^{14}$

Lebih lanjut, norma kelas menjelaskan mengapa siswa di beberapa ruang kelas lebih cenderung terlibat dalam intimidasi. Norma-norma yang menyulut dapat tercermin

12 Lihat, P. K. Smith, Understanding school bullying: Its nature and prevention strategies (London: Sage, 2014).

13 S. Saarento, et. al., "Reducing bullying and victimization: Student- and classroom-level mechanisms of change", Journal of Abnormal Child Psychology, Vol. 43 (2015): 61-76.

${ }^{14}$ C. Garandeau, et. al., “Inequality matters: Classroom status hierarchy and adolescents' bullying”, Journal of Youth and Adolescence, Vol. 43 (2014): 1123-1133. 
dalam rendahnya tingkat sikap anti-perundungan, dalam ekspektasi positif mengenai hasil sosial dari tindakan-tindakan proBullying dan harapan-harapan negatif dari hasilhasil sosial dari tindakan-tindakan pemberi-pelaku - masing-masing faktor ini terkait dengan risiko keterlibatan Bullying yang lebih tinggi di dalam kelas. Norma kelas juga dapat tercermin dari perilaku siswa saat menyaksikan tindakan Bullying. Karena reaksi teman sebaya dalam situasi intimidasi memberikan umpan balik langsung kepada pelaku intimidasi, mereka memiliki implikasi penting bagi munculnya dan pemeliharaan intimidasi. Frekuensi pelaku intimidasi memang lebih tinggi di ruang kelas di mana penguatan perilaku pelaku intimidasi adalah hal biasa dan jarang membela teman sekelas yang menjadi korban, yang menyiratkan bahwa intimidasi dihargai secara sosial. ${ }^{15}$

Oleh sebab itu, strategi guru PAl dalam menanggulangi perilaku Bullying ini sangat urgen, dimana guru PAI menjadi poros untuk keberhasilan dalam penanganan kasus ini, bermula dari perilaku Bullying yang ditemukan di sekolah seorang guru PAI harus mempunyai strategi kusus dalam penanganan agar bisa teratasi secara maksimal. Kita tahu bahwa perilaku Bullying siswa sangat tidak etis dilihat apalagi dalam lingkup pendidikan, namun hal ini tidak bisa di hindari lagi di setiap satuan pendidikan karena disanalah tempat berkumpul anak-anak yang sedang di masa pubertas dan beraneka ragam latar belakang kehidupan. Dalam penjelasan diatas sudah dijelaskan bahwa bentuk-bentuk Bullying siswa beraneka ragam. Niken membagi jenis-jenis Bullying kedalam empat macam, yaitu ${ }^{16}$; pertama, Bullying secara fisik, seperti memukuli, menendang, menampar, mencekik, menggigit, mencakar, meludahi, dan merusak serta menghancurkan barang-barang milik anak yang tertindas.

\section{Bentuk Bullying di SMP Negeri 2 Waru Sidoarjo}

Bullying dapat berdampak negatif pada semua siswa, khususnya mereka yang terlibat langsung dalam bullying. ${ }^{17}$ Perilaku intimidasi dapat dilakukan dengan cara menggoda dan memanggil nama (verbal), pengucilan sosial (relasional), hingga perilaku

\footnotetext{
15 Ibid.

16 Suryatmini Niken, Bullying: Mengatasi Kekerasan Di Sekolah Dan Lingkungan Sekitar Anak (Jakarta: PT. Grasindo, 2008). 9

17 D. S. J. Hawker \& M. J. Button, "Twenty years' research on peer victimization and psychosocial maladjustment: A meta-analytic review of cross-sectional studies", Journal a/Child Psychology and Psychiatry, Vol. 41 (2000): 441-455.
} 
seperti mendorong, menendang, atau berkelahi (fisik). ${ }^{18}$ Berdasarkan hasil wawancara dengan Bapak Drs. Asmuni, M.Pd. I selaku Guru PAl pada tanggal 15 Februari 2020, beliau menjelaskan sebagai berikut:

"Ya, ada Bullying, biasanya kejadian itu ditangkap ketika seseorang melaporkannya kepada saya, misalnya bertengkar. Seperti kemarin, kes antara DN dan DY, yang bertengkar karena saling mengancam melalui media sosial. Kemudian salah seorang dari mereka tidak menerimanya dan melaporkannya kepada gengnya di kampung. Jika untuk waktu itu biasanya setelah shalat dhuhur, waktu istihat, jam kosong atau ketika guru sedang dalam perjumpaan. Tempatnya biasanya di kantin, di lapangan juga atau ia boleh berlaku di dalam kelas."19

Lebih lanjut Bapak Asmuni menyampaikan:

"Kasus lain adalah bahawa saya pernah menghadapi tingkah laku buli daripada siswa, biasanya seperti bercakap tidak sesuai, seseorang sering mengatakan "as", janc*k, I*nte, p*rek, bed*s dll. Kadang-kadang menyembunyikan pena rakan, mencoret pakaian, juga saling menghujat di media sosial seperti kasus HF dan AR hanya kerana AR mengatakan bahawa HF adalah suatu keanehan, per * $k$, dan kemudian bertengkar di sekolah.."20

Peneliti menganalisis berdasarkan wawancara di atas bahwasanya perilaku Bullying yang terjadi di sekolah tidak terlihat secara langsung oleh para guru dan akan diketahui apabila perilaku tersebut sudah terjadi dan ada pengaduan dari pihak lain yang menyaksikan aksi tersebut. Hal ini menunjukkan bahwasanya perilaku Bullying yang dilakukan oleh siswa terjadi pada saat tidak adanya pengawasan oleh guru yang mana hal tersebut dapat kita lihat dari waktu terjadinya aksi Bullying secara fisik ini yakni pada saat sedang tidak dalam proses belajar mengajar atau dalam pengawasan guru. Penemuan yang peneliti temukan ini sesuai dengan hasil observasi yang telah dilakukan, yakni menunjukkan waktu yang paling sering terjadinya aksi ini adalah pada saat jam istirahat atau jam pelajaran yang kosong, karena waktu tersebut anak-anak bisa bebas bergaul tanpa adanya pengawasan penuh dari bapak/ibu guru.

Drs.Asmuni, M.Pd. I menjelaskan bahwa Tempat terjadinya aksi Bullying ini dilakukan ditempat yang tidak bisa dilihat oleh guru. Dikarenakan pada saat jam istirahat guru lebih banyak berada di ruang guru, menyebabkan anak lebih aktif bergaul ditempat yang jauh dari ruang guru, seperti di dalam kelas, kantin, dan sebagainya. Oleh karena itulah Drs.Asmuni, M.Pd. I tidak pernah melihat aksi Bullying ini secara langsung pada siswa.

18 C. A. Rose, et., al, "Bullying perpetration and victimization in special education: A review of the literature", Remedial and Special Education, Vol. 32 (2011): 114-130.

19 Wawancara Pribadi dengan Drs. Asmuni, M.Pd. I selaku guru PAI SMPN 2 Waru, 15 februari 2020.

20 ibid 
Bapak Hanif Arrozi, S.Psi selaku guru BK di SMP Negeri 2 Waru juga menyampaikan Hal serupa pada tanggal 16 Februari 2020, beliau mengatakan sebagai berikut:

“..Terdapat tingkah laku bullying fisik, seperti memukul kepala, membalikkan badan, mencubit, bertengkar, sementara yang lain mungkin mengejek rakan yang merasa lemah seperti berkata "anak h*ram", anak e p*imen, berkata kotor seperti "'janc*k". Saya tidak pernah melihatnya secara peribadi, tetapi saya sering mendapat aduan daripada orang lain atau guru lain. Sekiranya waktu biasanya pada waktu kelas kosong atau guru tidak dapat masuk dan juga semasa rehat. Sementara tempatnya di kelas, di padang atau di kantin. Pelakunya boleh jadi lelaki dan wanita, lelaki dan wanita, wanita dan wanita. Sekiranya tingkah laku itu berlaku, paling tidak penanganannya adalah memberi nasihat, memberi arahan, memberi bimbingan kepada anak, masalahnya ialah kaunselor tidak boleh memberikan hukuman kepada anak itu, paling banyak hanya sebatas memberi nasihat kepada anak.. ${ }^{21}$

Penjelasan yang telah dipaparkan oleh Bapak Hanif Arrozi, S.Psi ada beberapa hal yang sama dengan penjelasan yang disampaikan oleh Bapak Drs. Asmuni, M.Pd. I selaku Guru PAI, yakni waktu dan tempat kejadian perkara, kemudian kesamaan antara mereka berdua adalah mereka tidak melihat secara langsung aksi Bullying secara fisik yang dilakukan anak di sekolah, namun mereka hanya mengetahui apabila ada pengaduan dari orang lain. Walaupun begitu bentuk-bentuk aksi pengaduan yang diterima oleh guru BK lebih beragam seperti memukul kepala, menjulak-julak badan, dan mencubit, berkata kotor, menghina orang tuanya dengan sebutan Paimen, Slamet dll. Beliau juga menyampaikan bahwa guru BK tidak memberikan hukuman namun hanya berupa nasehat dan bimbingan saja. Peneliti rasa hal ini sangat kurang apabila tidak adanya hukuman yang diterapkan di sana, disebabkan tidak adanya efek jera yang diberikan apabila anak melakukan aksi Bullying secara fisik di sekolah. Pelaku dan korban yang dijelaskan oleh Bapak Hanif Arrozi, S.Psi.

Wawancara selanjutnya yang dilakukan peneliti adalah dengan Pak Kusdiyanto selaku satpam di sekolah pada tanggal 17 Februari 2020, ia menjelaskan sebagai berikut:

"Sekiranya penemuan tingkah laku bullying sering terjadi, contohnya seperti memukul badan, rakan jakak jakak, menepuk, palak, menendang kaki, menghina ibu bapanya, mengatakan kotor seperti janc*k, $a^{*} u, p^{*} r e k$, ganj*n, melempar benda ke teman. Biasanya ia berlaku ketika anak mempunyai waktu istirahat, jam kosong, olahraga, pada dasarnya jika tidak ada waktu belajar, malah kembali ke sekolah sering berbuat Tindakan bullying. Tempatnya biasanya di lapangan dan di Gazebo yang sering saya kenal. Ketika saya tiba, mereka segera pergi, takut kepada saya, malah kadang-kadang bertengkar di depan sekolah ketika waktu pulang.."22

21 Wawancara kepada Bapak Hanif Arozi, S.Psi selaku guru BK pada tanggal 16 februari 2020.

22 Wawanvara dengan satpam sekolah SMP Negeri 2 Waru pada tangga 17 februari 2020 
Berbeda dengan kedua informan di atas, penjelasan yang diberikan oleh satpam di SMP Negeri 2 Waru menunjukkan bahwa ia melihat secara langsung adanya perilaku Bullying di sekolah. Hal ini mungkin saja terjadi sebab dari hasil observasi yang peneliti lakukan di sana, peneliti mendapatkan bahwa siswa-siswi di SMP Negeri 2 Waru juga lebih aktif untuk melakukan aksi Bullying di pekarangan sekolah, bisa jadi hal ini yang menyebabkan satpam sering melihat adanya aksi Bullying di pekarangan sekolah. bentuk aksi Bullying yang disampaikan satpam ada beberapa tambahan yakni waktu terjadinya aksi Bullying juga terjadi apabila siswa hendak pulang sekolah, sehingga peneliti menganalisa bahwa aksi Bullying pada siswa tidak hanya ketika ia berada di sekolah saja namun juga terjadi di luar sekolah, dimana siswa sering membuat kelompok-kelompok (geng) dikarenakan sistem zonasi sekolah yang menjadi perkumpulan anak-anak yang dulunya di kampung sering akrab dan menjadi satu dalam sekolah.

Wawancara selanjutnya kami lakukan yaitu dengan Bapak Indira Tiardana Kusuma, S.Pd selaku waka kesiwaan SMP Negeri 2 Waru, pada tanggal 20 Februari 2020, beliau mengatakan sebagai berikut:

“..Tingkah laku bullying, sekiranya saya sendiri tidak tahu, tetapi jika ada aduan atau laporan, seringlah mendengar daripada guru lain. Contohnya, melekatkan badannya, memukul, menendang, kaki, menghina ibu bapanya, mengatakan perkara kotor seperti janc*k, a*u, $p^{*}$ rek, ganj*n itu ada. Sekiranya berdasarkan aduan guru lain, biasanya pada waktu kelas kosong atau waktu rehat. la boleh berada di kelas atau di lapangan, di kantin, atau di koperasi sekolah, dan biasanya lelaki dan wanita yang melakukan ini melakukannya. lelaki dengan lelaki, wanita dengan wanita. Sekiranya masalah siswa tidak dapat diselesaikan oleh guru maka saya akan mengambil alih dan berunding dengan pengetua. Apabila kasus itu sampai kepada saya, saya akan membuat surat perjanjian kepada siswa. Ya, sesuai dengan tingkatannya, dapat dengan perjanjian ringan terlebih dahulu, jika dia mengulanginya maka dia dapat diusir dari sekolah."23

Berdasarkan penjelasan yang diberikan Waka kesiswaan, peneliti menganalisa bahwa penyebab jarang atau tidak adanya temuan pihak guru atau sekolah terhadap aksi Bullying di sekolah dikarenakan siswa segan dan takut apabila melakukan aksi itu sampai ketahuan pihak kesiswaan apalagi sampai kepada kepala sekolah, karena jika ketahuna pelaku Bullying tersebuat akan dikeluarkan dari sekolah. hal inilah yang menyebabkan aksi tersebut baru ketahuan apabila sudah terjadi dan dilaporkan oleh orang lain. Kepala sekolah juga memegang peranan penting dalam penanganan kasus

${ }^{23}$ Wawancara Bersama Bapak Indira Tiardana Kusuma, S.Pd selaku waka kesiwaan SMP Negeri 2 Waru, pada tanggal 20 Februari 2020 
Bullying ini dilihat dari kinerjanya yang akan turun tangan langsung apabila kasus Bullying sudah tidak dapat diselesaikan oleh pihak guru.

Wawancara yang peneliti lakukan selanjutnya adalah dengan RD siswa kelas VII-K yang merupakan pelaku Bullying pada tanggal 20 Februari 2020, ia menjelaskan sebagai berikut:

Ketika melakukan bullying, pak, saya biasanya menarik rambut saya, menendang, menumbuk, menjulurkan badan saya, mencubit, menarik $\mathrm{BH}$, mendorong kepala, menggoda, dan menangis. Kadang-kadang saya pergi ke AR, NY, HF, kebanyakan waktu di kelas. Sekiranya tiba waktunya, kadang-kadang ketika anda ingin sholat dhuhur, ketika pulang dari sekolah, waktu rehat, waktu latihan, selalunya ia kosong, pak. Kami melakukannya kerana saya suka cari perhatian, sebenarnya ia adalah jenis nakal, tetapi di luar kebiasaan saya merasa senang jika saya menggodanya pak. ${ }^{24}$

Melalui penjelasan di atas peneliti menemukan hal baru, yakni peneliti menganalisa adanya kecenderungan aksi Bullying yang lebih sensitif berdasarkan pengakuan siswa. Sensitif dalam artian perlakuan yang dilakukan oleh pelaku mengarah kepada bagian vital korban seperti menarik tali BH. Temuan baru yang peneliti dapat dari wawancara di atas adalah bahwa perilaku Bullying yang dilakukan siswa tidak hanya bersifat homogen akan tetapi juga bersifat heterogen, maksudnya pelaku dan korban tidak hanya antara laki-laki dengan laki-laki atau perempuan dengan perempuan saja, tetapi juga dilakukan laki-laki dengan perempuan atau sebaliknya.

Pelaku dalam hal ini mengakui bahwa ia sangat senang dengan aksi yang ia lakukan kepada korban dikarenakan ia sudah terbiasa menjahili temanya, bisa jadi emang sudah faktor dari keluarganya yang kurang mendapat perhatian sehingga ia meluapkanya di sekolah.

Wawancara yang peneliti lakukan selanjutnya dengan NE selaku pihak ketiga yang melihat atau saksi aksi Bullying di kelasnya pada tanggal 25 Februari 2020, la memberikan penjelasan sebagai berikut:

"Tingkah laku bullying di kelas kami sangat kerap, Pak. Contohnya, banyak, seperti menarik jilbab, memukul badan, menggelitik satu sama lain, saling menendang, saling mengejar, saling menendang kaki, menarik $\mathrm{BH}$, menghina nama orang tua, mengatakan kasar dan kotor, DY dan DN adalah pelakunya. Korbannya biasanya AR, NY, HF. Tempatnya ada di dalam kelas yang sering Pak, kadang-kadang juga di kantin, saya juga kasihan dengan tuan, kadang-kadang anda menangis ketika dibuli seperti itu."25

\footnotetext{
24 Wawancara dengan RD pelaku Bullying di SMP Negeri 2 Waru pada tanggal 25 Mei 2020

${ }^{25}$ Wawancara pribadi dengan NE, saksi aksi Bullying pada tanggal 27 Februari 2020. 
Melalui penjelasan yang disampaikan oleh NE tersebut, peneliti tidak menemukan adanya data baru yang muncul, serta hanya sebatas pembenaran bahwasanya memang benar bahwa di kelasnya terjadi aksi Bullying siswa. Namun peneliti menemukan bahwa perilaku yang Nayla lakukan merupakan tindakan yang bisa memicu adanya aksi Bullying selanjutnya, dikarenakan ia tidak melaporkan aksi tersebut kepada guru atau diam dan hanya menikmati aksi Bullying yang diterima oleh temannya.

Wawancara terakhir adalah dengan HLB, selaku korban dalam aksi Bullying di kelasnya pada tanggal 27 Februari 2020. Ia menerangkan sebagai berikut:

“..Kami sering dibuli dengan DN, Pak. Dan yang paling sering adalah AR, Pak. Sehingga kadang-kadang kita menangis, kita sering didorong, ditarik oleh jilbab, dicubit, ditarik, kadang-kadang digoda dengan kata kotor. Saya pernah menangis, Pak. Kadang-kadang di kelas, di kantin, koperasi, bilik seni, di padang. Kadang-kadang kita kesal, Pak, sangat kesal, Pak. Saya ingin melapor kepada BK tetapi tidak berani takut bahawa dia akan diancam di luar sekolah."26

Berdasarkan hasil wawancara yang dilakukan dengan korban, peneliti menemukan adanya pengakuan dari korban bahwa ia memang sering mendapatkan perlakuan Bullying oleh temannya Penjelasan bentuk Bullying yang ia jelaskan sama dengan penjelasan yang disampaikan oleh pelaku sebelumnya. Peneliti menduga alasan kenapa ia dibully disebabkan sikap diam dan tidak melawan yang dilakukan oleh korban terhadap pelaku, sehingga pelaku merasa lebih kuat dan mendominasi tanpa takut adanya perlawanan dari si korban, serta disebabkan karena korban merasa takut dan diancam oleh pelaku dan masalah akan semakin besar, mengingat pelaku salah satu siswa yang mempunyai kelompok besar (geng) di luar sana.

Dalam penemuan yang peneliti amati bentuk perilaku Bullying yang siswa lakukan adalah seperti mendorong badan, mencubit, menendang kaki, melempari barang, meninju, memukul teman, kejar-kejaran, menarik tali $\mathrm{BH}$, mengejek nama orang tua, berkata kotor atau kasar, dan sebagainya. Hal ini juga serupa dengan teori yang telah kami jelaskan sebelumnya, kami menjelaskan bahwa jenis Bullying Bullying di antaranya adalah memukul, mencekik, menyikut, meninju, menendang, menggigit, memiting, mencakar, menghina orang tua, berkata kasar, serta meludahi anak yang ditindas hingga ke posisi yang menyakitkan, merusak dan menghancurkan pakaian serta barang-barang milik anak yang tertindas. ${ }^{27}$

${ }^{26}$ Wawancara pribadi dengan HLB, korban Bullying di SMPN 2 Waru pada tanggal 27 Februari 2020

27 Zakiyah, "Faktor yang Mempengaruhi Remaja dalam Melakukan Bullying”, Jurnal Penelitian \& PPM, Vol. 4. No. 2 (2017): 329. 
Berdasarkan teori ini kita ambil kesimpulan bahwa tidak semua aksi yang diteorikan sama dengan yang terjadi di sekolah, persamaan perilaku di SMP Negeri 2 Waru dengan teori yang ada hanya pada perilaku seperti memukul, meninju dan menendang, menarik tali BH, mengejek nama orang tua, berkata kotor atau kasar. Dari hal tersebut sangat cocok pada perilaku anak yang ada di SMP Negeri 2 Waru untuk dikatakan sebagai perilaku Bullying secara fisik dan verbal, karena peneliti hanya menemukan data yang sedemikain.

\section{Strategi Guru PAI dalam Menangani Tindakan Bullying Siswa}

Berdasarkan hasil wawancara dengan Bapak Drs. Asmuni, M.Pd.I selaku Guru PAI tentang bagaimana strategi dalam menangani perilaku Bullying secara fisik pada tanggal 03 Maret 2020. Beliau mengatakan sebagai berikut:

“..Dalam menangani kasus ini strategi yang saya gunakan adalah menasehati atau dengan ceramah, yakni memberikan pengajaran kepada mereka seperti memberikan cerita-cerita Islami, atau cerita yang real yang terjadi di masyarakat kalau misal kita melakukan itu maka akibatnya akan begini. Misalnya sebelum mulai jam pelajaran Bapak akan memberikan nasehat dan ceramah. Kalau untuk hukuman ya, paling sebatas hukuman ringan seperti menulis surat-surat pendek, disuruh menghafal ayat Kursi, membersihkan masjid, toilet. Hukuman disini kami berikan bukan dalam bentuk fisik, karena undang-undang sudah memberikan aturan jika menghukum siswa tidak boleh memakai fisik, karena bias masuk pidana perihal kekerasan dalam anak. Sudah bnyak kasus yang terjadi di TV nasional, guru dipenjara hanya karena mencubit muridnya. Tapi sebenarnya untuk hukuman itu Bapak tidak pernah memberikan hukuman sepihak, Bapak akan memberikan hukuman apabila sudah dikonsultasikan dengan wali kelas dan BK, dan juga orang tua murid dipanggil kalau kami sudah sepakat baru hukuman bisa dilakukan misal dengan memberi skors 2 minggu tergantung jenjangnya dan tingkat kelakuan buruknya. Jadi Bapak tidak bisa menetapkan hukuman secara sepihak.."28

Melalui penjelasan tersebut, peneliti menganalisis bahwa tahap pertama yang beliau lakukan adalah dengan menasehati atau ceramah dengan memberikan pengajaran kepada siswa seperti menceritakan sebuah kisah. Islam inspiratif atau cerita yang real dan terjadi di dalam masyarakat sekitar. Serta memberikan pengetahuan tentang dampak yang ditimbulkan dari aksi Bullying tersebut.

Sedangkan hukuman yang diberikan kepada siswa beragam, apabila kasus tersebut masih dalam kategori ringan, maka hanya berupa hukuman menulis surat-surat pendek, disuruh menghafal ayat Kursi, membersihkan masjid, toilet, mengaji dll yang bersifat mendidik keislaman.

\footnotetext{
${ }^{28}$ Wawancara Pribadi dengan Drs. Asmuni, M.Pd.I selaku guru PAI SMPN2 Waru, 03 Maret 2020.
} 
Apabila kasusnya sudah masuk dalam kategori berat maka dirinya tidak bisa memberikan hukuman secara sepihak, dalam artian beliau akan membicarakannya terlebih dahulu kepada wali kelas dan guru BK disertai dengan memanggil orang tua dari siswa tersebut untuk ditindak lanjuti. Setelah itu baru bisa disepakati hukuman apa yang cocok untuk siswa tersebut, seperti hukuman siswa terdahulu yakni skors selama 1 minggu. Hukuman bisa berubah sesuai dengan tingkat kasus kenakalan yang dilakukan anak.

“..Hal ini serupa dengan keterangan yang disampaikan oleh guru BK Bapak Hanif Arozi, S.Psi bahwa mereka tidak bisa memberikan hukuman secara sepihak dan hanya memberikan pengarahan, teguran dan nasehat kepada siswa apabila ada sebuah kasus yang sampai ke ruang BK.."29

Berdasarkan hasil wawancara terakhir dengan Bapak Drs. Asmuni, M.Pd.I selaku Guru PAI tentang bagaimana strategi dalam menangani perilaku Bullying siswa yang terjadi di SMP Negeri 2 Waru pada tanggal 07 Maret 2020. Beliau mengatakan sebagai berikut:

“..Kalau Bapak untuk penanganan dalam kasus bullying ini adalah Bapak akan kasih pemahaman dan menasehati, Bapak ambil kedua anak itu terus Bapak jelaskan kepada mereka bahwa perbuatan mereka itu tidak baik dan bisa menyebabkan dosa serta tidak baik untuk dilakukan kepada teman sesama. Bapak akan memberi pemahaman atau menasehati mereka untuk selalu saling mengasihi antar sesama kita dan saling bermusuhan. Kalau untuk hukuman ya Bapak tidak ada memberikan hukuman, mungkin hanya sebatas nasehat saja dan pemberian pemahaman kepada anak itu saja.."30

Berdasarkan penjelasan dari beliau peneliti menganalisa bahwa penanganan yang ia berikan adalah dengan menasehati, yakni dengan cara mengambil kedua anak tersebut lalu diberi penjelasan dan ceramah tentang bahaya Bullying dan dampak serta akibat yang akan ditimbulkan setelahnya, serta memberikan pemahaman bahwa sesama muslim harus saling mengasihi dan tidak boleh bermusuhan. Kemudian pelaku Bullying akan di pantau terus menerus perkembanganya sampai benar-benar topbat, Sedangkan untuk hukuman, beliau tidak memberikan hukuman kepada anak tersebut dan beliau hanya sebatas pemberian nasehat saja kepada siswa.

Dalam menangani kasus Bullying ini guru PAl mempunyai strategi strategi yang pertama adalah pemberian nasehat atau ceramah, yakni pemberian pemahaman bahwa perilaku tersebut tidak baik atau pemberian cerita-cerita Islami atau cerita yang benarbenar terjadi di masyarakat sebagai pelajaran dan untuk memberikan motivasi agar mendorong anak melakukan hal-hal yang baik. Sedangkan hukuman yang diberikan

29 Wawancara kepada guru BK Bapak Hanif Arozi, S.Psi pada tanggal 03 Maret 2020

30 Wawancara kepada Bapak Drs. Asmuni, M.Pd.I selaku Guru PAl pada tanggal 07 Maret 2020 
kepada siswa beragam, apabila kasus tersebut masih dalam kategori ringan, maka hanya berupa hukuman menulis surat-surat pendek, disuruh menghafal ayat Kursi, membersihkan masjid, toilet, mengaji dll yang bersifat mendidik keislaman, Hal ini mungkin didasari bahwa hukuman tersebut merupakan hukuman yang tidak memberatkan bagi anak dan tidak membuat anak mengalami cidera dan berbau hukum.

Apabila sudah kasus Bullying menjadi kasus yang berat maka guru PAl akan mendiskusikan kepada guru wali kelas, guru BK dan memanggil kedua orang tua siswa yang bersangkutan, sehingga hukuman selanjutnya yang akan diberikan kepada anak nanti adalah hasil kesepakatan bersama dan bukan berasal dari guru PAl saja, seperti pemberian skor selama 1 minggu kepada siswa. Tetapi, apabila tidak bisa diselesaikan oleh mereka maka kasus tersebut akan di bawa ke Kepala Sekolah.

Guru PAl tidak secara langsung memberikan hukuman kepada siswa apabila siswa itu melakukan kasus Bullying yang berat, ia hanya menjadi perantara serta meminta bantuan pihak lain untuk menyelesaikan permasalahan anak tersebut. maka guru PAI, wali kelas serta guru BK akan mendiskusikan hukuman yang tepat untuk anak karena pedoman hukumannya sudah ada. Apabila tidak dapat diselesaikan oleh mereka maka akan ditangani langsung oleh Kepala Sekolah dengan solusi yang diberikan adalah menyuruh anak membuat surat perjanjian untuk tidak mengulangi tindakan tersebut, yang apabila masih dilakukan maka ia akan dikeluarkan di sekolah. Hal ini dikarenakan pihak guru BK tidak bisa memberikan hukuman secara sepihak, pihak BK hanya bisa memberikan pengarahan, bimbingan dan nasehat kepada siswa, dan apabila ingin diberi hukuman maka hukuman itu harus berdasarkan kesepakatan bersama dengan guru lain.

\section{E. Kesimpulan}

Dalam menangani kasus bullying, guru PAI di SMPN 2 Waru Sidoarjo mempunyai strategi: pertama, melalui ceramah. Ceramah dilakukan melalui nasihat, cerita yang benar-benar terjadi di masyarakat sebagai pelajaran dan untuk memberikan motivasi agar mendorong anak melakukan hal-hal yang baik. Kedua, pemberian hukuman. Apabila kasus tersebut masih dalam kategori ringan, maka hanya berupa hukuman menulis suratsurat pendek, disuruh menghafal ayat Kursi, membersihkan masjid, toilet, mengaji dan lain sebagainya. Apabila terjadi kasus yang berat maka guru PAl akan mendiskusikan kepada guru wali kelas, guru BK dan memanggil kedua orang tua siswa yang bersangkutan, sehingga hukuman selanjutnya yang akan diberikan kepada anak nanti 
adalah hasil kesepakatan bersama. Penulis memberikan rekomendasi bahwa guru untuk terus mengawasi siswa baik secara langsung atau tidak langsung terhadap aktivitas siswa ketika berada di sekolah. Untuk pihak sekolah, hendaknya memberikan ketegasan dan hukuman yang pantas untuk kasus Bullying yang terjadi pada siswa. Perlunya interaksi yang baik antara guru dan orang tua sehingga perkembangan akhlak siswa dapat dipantau baik di sekolah maupun di luar sekolah.

\section{Referensi}

Fajar Shidiqi, Muhammad., dan Suprapti, Veronika. "Pemaknaan Bullying pada Remaja Penindas(The Bully)", Jurnal Psikologi Keperibadian dan Sosial, Vol. 2, No. 2 (Agustus 2013): 23.

Fanti, K. A., \& Kimonis, E. "Bullying and victimization: The role of conduct problems and psychg b vbgbggbgb c opathic traits", Journal of Research on Adolescence, Vol. 22 (2012): 617-631.

Farrington, D. F. “Understanding and preventing Bullying”, Crime and Justice, Vol. 17 (1993): 381-458.

Fitri Nur Aini, Dian. "Self Esteem Pada Anak Usia Sekolah Dasar Untuk Pencegahan Kasung Bullying", Jurnal Pemikian dan Pengembangan SD, Vol. 6, No. 1 (April 2018): 38.

Garandeau, C. et. al., 'Inequality matters: Classroom status hierarchy and adolescents' Bullying”, Journal of Youth and Adolescence, Vol. 43 (2014): 1123-1133.

Hatta, Ahmad. Tafsir Qur'an Per Kata Dilengkapi Dengan Asbabun Nuzul \& Terjemah. Jakarta: Maghfirah Pustaka, 2009.

Hymel, S. \& Swearer, S.M. "Four decades of research on school Bullying: An introduction”, American Psychologist, Vol. 70 (2015): 293-299.

Niken, Suryatmini. Bullying: Mengatasi Kekerasan Di Sekolah Dan Lingkungan Sekitar Anak. Jakarta: PT. Grasindo, 2008).

Saarento, et. al., "Reducing Bullying and victimization: Student- and classroom-level mechanisms of change", Journal of Abnormal Child Psychology, Vol. 43 (2015): 6176.

Smith, P. K. Understanding school Bullying: Its nature and prevention strategies. London: Sage, 2014.

Tawalujan, Aprilia Eunike., Dkk,. "Hubungan Bullying dengan Kepercayaan Diri Pada remaja di SMP Negeri 10 Manado", e-Journal keperawatan, Vol. 6, No. 1 (Mei 2018): 2 .

Wardhana, Katyana. Buku Panduan Melawan Bullying. ebook: tp, 2016. 
Zakiyah. "Faktor yang Mempengaruhi Remaja dalam Melakukan Bullying”, Jurnal Penelitian \& PPM, Vol. 4. No. 2 (2017): 329.

Lickona, Thomas. Educating for Character: How Our Schools Can Teach Respect and Responsibility. New York : Bantam Books., 1991.

Sanaky, Hujair AH. "The Role of Religious Education in Forming Tolerant Individuals". Indonesian Journal of Interdisciplinary Islamic Studies, Vol. 1, No. 1_(September 2017).

Hawker, D. S. J. and Boulton, M. J. "Twenty years' research on peer victimization and psychosocial maladjustment: A meta-analytic review of cross-sectional studies". Journal a/Child Psychology and Psychiatry, Vol. 41 (2000): 441-455.

Rose, C. A., et., al. "Bullying perpetration and victimization in special education: A review of the literature”. Remedial and Special Education, Vol. 32 (2011):114-130.

\section{Hasil Wawancara}

Asmuni, Wawancara, Sidoarjo, 15 Februari 2020.

Hanif Arozi, Wawancara, Sidoarjo, 16 Februari 2020.

Indira Tiardana Kusuma, Wawancara, Sidoarjo, 20 Februari 2020

RD, Wawancara, Sidoarjo, 25 Mei 2020

NE, Wawancara, Sidoarjo, 27 Februari 2020.

HLB, Wawancara, Sidoarjo, 27 Februari 2020. 